\title{
The insulin receptor substrate 1 associates with phosphotyrosine phosphatase SH PTP2 in liver and muscle of rats
}

M.H.M. Lima,

J.E. Zambelli ${ }^{1}$,

C.R.O. Carvalho ${ }^{1}$ and M.J.A. Saad ${ }^{1}$
Departamentos de ${ }^{1}$ Clínica M édica, Faculdade de Ciências M édicas, and 2Fisiologia e Biofísica, Instituto de Biologia, Universidade Estadual de Campinas, Campinas, SP, Brasil

\section{Correspondence \\ M.J.A. Saad \\ Departamento de Clínica Médica \\ FCM, UNICAMP \\ 13081-970 Campinas, SP \\ Brasil \\ Fax: +55-19-239-3114 \\ Presented at the XIII Annual Meeting of the Federação de Sociedades de Biologia Experimental, Caxambu, MG, Brasil, August 26-29, 1998.}

Research supported by FAPESP and CNPq (PRONEX).

Received April 14, 1998 Accepted August 13, 1998

\section{Abstract}

Insulin stimulates the tyrosine kinase activity of its receptor resulting in the phosphorylation of its cytosolic substrate, insulin receptor substrate-1 (IRS-1) which, in turn, associates with proteins containing $\mathrm{SH} 2$ domains. It has been shown that IRS-1 associates with the tyrosine phosphatase SHPTP2 in cell cultures. While the effect of the IRS-1/SHPTP2 association on insulin signal transduction is not completely known, this association may dephosphorylate IRS-1 and may play a critical role in the mitogenic actions of insulin. However, there is no physiological demonstration of this pathway of insulin action in animal tissues. In the present study we investigated the ability of insulin to induce association between IRS-1 and SHPTP2 in liver and muscle of intact rats, by co-immunoprecipitation with anti-IRS-1 antibody and anti-SHPTP2 antibody. In both tissues there was an increase in IRS-1 association with SHPTP2 after insulin stimulation. This association occurred when IRS-1 had the highest level of tyrosine phosphorylation and the decrease in this association was more rapid than the decrease in IRS-1 phosphorylation levels. The data provide evidence against the participation of SHPTP2 in IRS-1 dephosphorylation in rat tissues, and suggest that the insulin signal transduction pathway in rat tissues is related mainly to the mitogenic effects of the hormone.

The insulin receptor is the principal mediator of insulin action on cellular and metabolic processes. The insulin receptor $\beta$-subunit, which contains an intrinsic tyrosine kinase, undergoes tyrosyl autophosphorylation and is activated in response to insulin binding to the extracellular $\alpha$-subunit (1). Moreover the discovery of the tyrosine kinase activity of the insulin receptor sug-

\section{Key words}

- Insulin action

- Insulin receptor substrate

- Phosphotyrosine

phosphatase

- SHPTP2 gested that the mechanism of insulin action involved the tyrosyl phosphorylation of intracellular substrates. An insulin-stimulated phosphoprotein called pp185 was identified in many cells and tissues using anti-phosphotyrosine antibodies. One component of the pp185 band was purified and cloned from several sources (2-4) and the cloned protein was called insulin receptor substrate 
1 (IRS-1). Evidence from different sources has shown that the phosphotyrosine-containing form of IRS-1 binds to the enzyme phosphatidylinositol 3-kinase (PI 3-kinase) through the Src homology 2 (SH2) domains of the latter $(4,5)$ and that this association activates the enzyme.

In addition to PI 3-kinase, other proteins containing SH2 domains such as SHPTP2, Nck, Grb2 have been shown to bind to IRS1 (1). SHPTP2 is an SH2 domain-containing tyrosine phosphatase that associates with the $\mathrm{COOH}$-terminal tyrosine phosphorylation sites of IRS-1 in cell cultures (6), and this association increases the phosphatase activity of SHPTP2 in vitro (7). However, there is no physiological demonstration of this pathway of insulin action in animal tissues. In the present study we investigated the ability of insulin to induce association of IRS-1 and SHPTP2 in liver and muscle of intact rats, two of the main target tissues for insulin action.

The rats were anesthetized with sodium amobarbital $(15 \mathrm{mg} / \mathrm{kg}$ body weight, intraperitoneally) and used in the experiments 10-15 min later, as soon as anesthesia was assured by the loss of foot and corneal reflexes. The abdominal cavity was opened, the vena cava exposed and $0.5 \mathrm{ml}$ saline $(0.9 \% \mathrm{NaCl})$, containing or not $6 \mu \mathrm{g}$ of insulin, was injected. After the indicated time, the liver or muscle was removed, minced coarsely and immediately homogenized in extraction buffer (1\% Triton X-100, 100 $\mathrm{mM}$ Tris, pH 7.4, containing $100 \mathrm{mM}$ sodium pyrophosphate, $100 \mathrm{mM}$ sodium fluoride, $10 \mathrm{mM}$ EDTA, $10 \mathrm{mM}$ sodium vanadate, $2 \mathrm{mM}$ PMSF and $0.1 \mathrm{mg}$ aprotinin $/ \mathrm{ml}$ ) at $4^{\circ} \mathrm{C}$ with a Polytron PTA $20 \mathrm{~S}$ generator (Brinkmann Instruments model PT 10/35; Westbury, NY) operated at maximum speed for $30 \mathrm{~s}$. Both extracts were centrifuged at $15,000 \mathrm{rpm}$ and $4^{\circ} \mathrm{C}$ in a Beckman $70.1 \mathrm{Ti}$ rotor (Palo Alto, CA) for $45 \mathrm{~min}$ to remove insoluble material, and the supernatant of these tissues was used for immunoprecipita- tion with anti-IRS-1 antibody and protein A Sepharose $6 \mathrm{MB}$. The samples were treated with Laemmli sample buffer (8) containing $100 \mathrm{mM}$ DTT, heated in a boiling water bath for $4 \mathrm{~min}$ and submitted to SDS-PAGE (6.5\% Tris/acrylamide). Electrotransfer of proteins from the gel to nitrocellulose was performed for $2 \mathrm{~h}$ at $100 \mathrm{~V}$ (constant) in the Bio-Rad miniature transfer apparatus (Mini-protean), as described by Towbin et al. (9) but with $0.02 \%$ SDS added to the transfer buffer to enhance the elution of high-molecular mass protein. Nonspecific protein binding to nitrocellulose was reduced by pre-incubating the filter overnight at $4^{\circ} \mathrm{C}$ in blocking buffer (3\% BSA, $10 \mathrm{mM}$ Tris, $150 \mathrm{mM} \mathrm{NaCl}$ and $0.02 \%$ Tween 20). The pre-stained molecular mass standards used were myosin (205 $\mathrm{kDa})$, galactosidase (116 kDa), BSA (80 $\mathrm{kDa})$ and ovalbumin $(49.5 \mathrm{kDa})$. The nitrocellulose blot was incubated with anti-phosphotyrosine $(1 \mu / \mathrm{ml})$ or anti-SHPTP2 $(1: 100)$ antibodies for $4 \mathrm{~h}$ at $22^{\circ} \mathrm{C}$. Monoclonal antiphosphotyrosine antibody and anti-IRS- 1 and anti-SHPTP2 antibodies were from Santa Cruz Biotechnology, Santa Cruz, CA. The blots were subsequently incubated with 2 $\mu \mathrm{Ci}\left[{ }^{125} \mathrm{I}\right]$-protein $\mathrm{A}(30 \mu \mathrm{Ci} / \mu \mathrm{g})$ in $10 \mathrm{ml}$ of blocking buffer for $1 \mathrm{~h}$ at $22^{\circ} \mathrm{C}$ and washed again. $\left[{ }^{125} \mathrm{I}\right]$-protein $\mathrm{A}$ bound to the antibodies was detected by autoradiography using preflashed Kodak XAR film with Cronex Lightning Plus intensifying screens at $-70^{\circ} \mathrm{C}$ for $12-48 \mathrm{~h}$. Band intensities were quantified by optical densitometry (Molecular Dynamics) of the developed autoradiogram (1012).

To estimate the rate of insulin-induced IRS-1 phosphorylation in the liver, we performed a time course experiment after the administration of insulin into the portal vein. Liver extracts were immunoprecipitated with anti-IRS-1 antibody and blotted with antiphosphotyrosine antibody. As shown in Figure 1A, $30 \mathrm{~s}$ after exposure to insulin there was a substantial increase in the phosphorylation of IRS-1, the rate of which decreased 

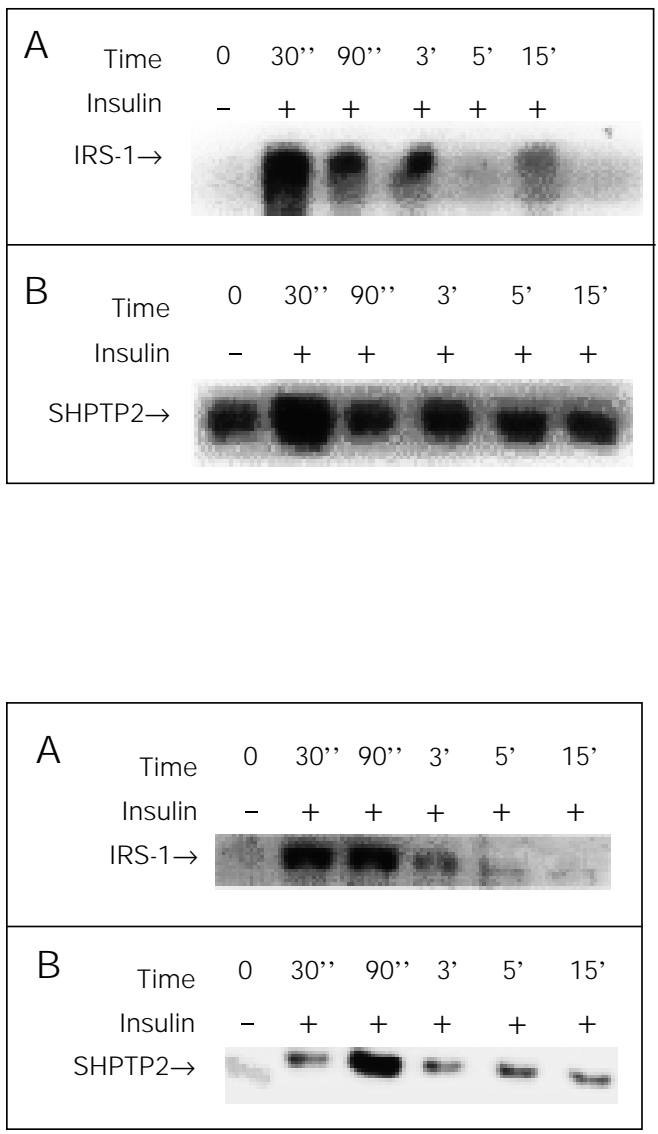

thereafter and had almost vanished by 15 min. In order to investigate the association of SHPTP2 with IRS-1 the same membrane was stripped and re-blotted with anti-SHPTP2 antibody. Figure 1B shows that there is a basal association between IRS-1 and SHPTP2 which increases $30 \mathrm{~s}$ after insulin infusion and returns to basal levels thereafter. It is interesting to note that at $90 \mathrm{~s}$ and $3 \mathrm{~min}$ after insulin infusion there still was IRS-1 tyrosine phosphorylation, but the association with SHPTP2 was just basal.

The results obtained for muscle were similar to those obtained for liver but high tyrosine phosphorylation levels of IRS-1 were observed at 30 and $90 \mathrm{~s}$ after insulin infusion (Figure 2A). When these samples previously immunoprecipitated with anti-IRS- 1 antibody were blotted with anti-SHPTP2 antibody, an important association was observed $30 \mathrm{~s}$
Figure 1 - Time course of insulin-stimulated IRS-1 tyrosine phosphorylation (panel A) and association with SHPTP2 in rat liver (panel B). Rats were anesthetized and the abdominal wall was incised to expose the viscera. Saline or insulin was infused at the indicated time. The tissues were excised and homogenized in extraction buffer at $4^{\circ} \mathrm{C}$ as described in the text. After centrifugation, aliquots containing equal amounts of protein were immunoprecipitated with anti-IRS- 1 antibody and protein A Sepharose 6 MB and then resolved on $6.5 \%$ SDS-polyacrylamide gels. The protein bands were subsequently transferred to a nitrocellulose membrane and detected with anti-phosphotyrosine antibody (A) or anti SHPTP2 (B) and [ ${ }^{125}$ I]-protein A, after which the membrane was subjected to autoradiography. The data are representative of five experiments.

Figre 2 - Time course of insulin-stimulated IRS-1 tyrosine phosphorylation (panel A) and association with SHPTP2 in rat muscle (panel B). Rats were anesthetized and the abdominal wall was incised to expose the viscera. Saline or insulin was infused at the indicated time. The tissues were excised and homogenized in extraction buffer at $4^{\circ} \mathrm{C}$ as described in the text. After centrifugation, aliquots containing equal amounts of protein were immunoprecipitated with anti-IRS-1 antibody and immunoblotted as described in the legend to Figure 1 . The data are representative of four experiments.

after insulin infusion, which was dissociated from IRS- 1 tyrosine phosphorylation, whose levels continued to be high up to $90 \mathrm{~s}$.

The results presented here show that SHPTP2 associates with phosphorylated IRS1 in liver and muscle of rats. In cell culture, SHPTP2 is activated during association with IRS-1. While the effect of IRS-1/SHPTP2 association on signal transmission is not completely known, there is a possibility that this interaction autoregulates IRS-1 phosphorylation. The tyrosine phosphatase SHPTP2 may dephosphorylate signaling intermediates located either in the IRS-1 signaling complex or at distant sites, thus downregulating signaling. In this regard, there is a study showing that SHPTP2 is able to dephosphorylate IRS-1 in vitro (13), but this phenomenon was not observed in vivo (1416). Our results showing that IRS-1/SHPTP2 
association occurs when IRS-1 has the highest level of tyrosine phosphorylation are evidence against the effect of SHPTP2 dephosphorylating IRS-1, and suggest that this association depends on an important increase in IRS-1 tyrosine phosphorylation.

The role of SHPTP2 in insulin signaling has been examined by several approaches. Microinjection of the $\mathrm{SH} 2$ domains of SHPTP2 or antibodies against SHPTP2 blocks insulin-stimulated DNA synthesis $(14,17)$. Similarly, overexpression of a catalytically inactive mutant SHPTP2 molecule inhibits mitogenesis and $\mathrm{p} 21^{\text {ras }}$ and MAP kinase activation (14-17). It is not clear how SHPTP2 transmits signals to $\mathrm{p} 21^{\text {ras }}$ and MAP kinase or mediates mitogenesis during insulin signaling, but there is no doubt that the activity of SHPTP2 plays a critical role in the mitogenic actions of insulin.

It is known that insulin activates hexose transport via at least two mechanisms: a p2 $1^{\text {ras }}$-dependent pathway leading to an increase in the amount of cell surface GLUT 1, and a metabolic, p2 $1^{\text {ras }}$-independent pathway leading to translocation of the insulinresponsive transporter GLUT 4 to the cell surface $(1,7)$. Hausdorff et al. (17), using microinjection of a glutathione S-transferase fusion protein encoding the $\mathrm{N}$ - and C-terminal SH2 domains of SHPTP2 or anti-SHPTP2 antibodies into 3T3-L1 adipocytes, demonstrated that SHPTP2 is important for the expression of GLUT 1, but is not required for activation of GLUT 4 translocation. These data suggest that SHPTP2 plays a role in the insulin-induced transcription of immediate early genes such as GLUT 1, but is not required for the metabolic increase in transport mediated by GLUT 4 translocation.

In summary, the present results demonstrate that after insulin stimulation of liver and muscle of intact rats there is an increase in the association of IRS-1 with SHPTP2, a pathway that has been shown to play an important role in insulin-induced DNA synthesis in cell culture.

\section{References}

1. White MF \& Kahn CR (1994). The insulin signaling system. Journal of Biological Chemistry, 269: 1-5.

2. White MF, Maron R \& Kahn CR (1985). Insulin rapidly stimulates tyrosine phosphorylation of an $\mathrm{Mr} 185000$ protein in intact cells. Nature, 318: 183-186.

3. Keller SR, Aebersold RH, Garner CW \& Lienhard GE (1993). The insulin-elicited $160 \mathrm{kDa}$ phosphotyrosine protein in mouse adipocytes is an insulin receptor substrate 1: identification by cloning. Biochimica et Biophysica Acta, 1172: 323326.

4. Sun XJ, Rothenberg PL, Kahn CR, Backer J M, Araki E, Wilden P, Cahill DA, Goldstein BJ \& White MF (1991). Structure of the insulin receptor substrate IRS1 defines a unique signal transduction protein. Nature, 352: 73-77.

5. Carvalho $C R O$, Brenelli $S L$, Silva $A C$, Nunes ALB, Velloso LA \& Saad MJA (1996). Effect of aging on insulin receptor, insulin receptor substrate-1 and phosphatidylinositol 3-kinase in liver and muscle of rats. Endocrinology, 137: 151-159.

6. Kuhné MR, Pawson T, Lienhard GE \& Feng GS (1993). The insulin receptor substrate 1 associates with the SH2-containing phosphotyrosine phosphatase syp. J ournal of Biological Chemistry, 268: 11479-11481.

7. Myers MG \& White FM (1996). Insulin signal transduction and the IRS-1 proteins. Annual Review of Pharmacology and Toxicology, 36: 615-658.

8. Laemmli UK (1970). Cleavage of structural proteins during the assembly of the head of bacteriophage T4. Nature, 227: 680-685.

9. Towbin H, Staehlin J \& Gordon J (1979). Electrophoretic transfer of proteins from polyacrylamide gels to nitrocellulose sheets. Procedure and some applications. Proceedings of the National Academy of Sciences, USA, 76: 4350-4354.

10. Saad MJ A, Carvalho CRO, Thirone ACP \& Velloso LC (1996). Insulin induces tyrosine phosphorylation of J ak2 in insulin-sensitive tissues of the intact rat. J ournal of
Biological Chemistry, 271: 22100-22104.

11. Thirone ACP, Carvalho CRO, Brenelli SL, Velloso LA \& Saad MJ A (1997). Effect of chronic growth hormone treatment on signal transduction in rat tissues. Molecular and Cellular Endocrinology, 130: 3342.

12. Saad MJ A, Maeda L, Brenelli SL, Carvalho CRO, Paiva RS \& Velloso LA (1997). Defects in insulin signal transduction in liver and muscle of pregnant rats. Diabetologia, 40: 179-186.

13. Sugimoto S, Wandless TJ, Shoelson SE, Nell BG \& Walsh CT (1994). Activation of the $\mathrm{SH} 2$-containing protein tyrosine phosphatase, SHPTP2, by phosphotyrosinecontaining peptides derived from insulin receptor substrate-1. J ournal of Biological Chemistry, 269: 13614-13622.

14. Milarski KL \& Saltiel AR (1994). Expression of catalytically inactive syp phosphatase in 3T3 cells blocks stimulation of mitogen-activated protein kinase by insulin. J ournal of Biological Chemistry, 269: 21239-21243. 
15. Yamauchi K, Ribon V, Saltiel AR \& Pessin JE (1995). Identification of the major SHPTP2-binding protein that is tyrosinephosphorylated in response to insulin. Proceedings of the National Academy of Sciences, USA, 270: 17716-17722.
16. Yamauchi $K$, Milarski $K L$, Saltiel $A R \&$ Pessin J E (1995). Protein-tyrosine-phosphatase SHPTP2 is a required positive effector for insulin downstream signaling. Proceedings of the National Academy of Sciences, 92: 664-668.
17. Hausdorff FS, Bennett AM, Neel BG \& Biirnbaum MJ (1995). Different signaling roles of SHPTP2 in insulin-induced GLUT1 expression and GLUT4 translocation. J ournal of Biological Chemistry, 268: 11479-11881. 


\section{David Rockefeller Center For Latin American Studies - Harvard University "Lemann Visiting Scholars and Fellows Program" Brasil}

The David Rockefeller Center for Latin American Studies, Harvard University, invites candidates for its "Visiting Scholars and Fellows Program". The "Visiting Scholars and Fellows Program" is a program for academic and non-academic professionals interested in developing research for a determined period of time (one or two academic semesters) while residing at Harvard University. The selection of professionals is made by an examination.

With the support of Mr. Jorge Paulo Lemann, the Center recently created the "Lemann Visiting Fellowship". This is a fellowship for a professional for the above mentioned program whose research project has Brazil as the study objective. This fellowship is awarded once each academic year (September-June) and covers the administrative expenses of the Center and airline tickets. The professional will also receive financial assistance of US\$15,000 (fifteen thousand American dollars, subject to income tax), regardless of the number of semesters for which he is accepted.

Registration Process: Candidates must be academic or nonacademic professionals who have completed their doctorate degree or equivalent academic preparation, fluent in English and have a substantial number of publications. Registration can be made for one academic semester or for the entire academic year (1 September 1998 to 30 June 1999). The deadline for registration for the 2nd semester of 1998 and for the above cited academic year is 1 April 1998. The deadline for registration for the 1 st semester of 1999 is 31 October 1998. All documentation will be analyzed by an interdisciplinary panel of professors of the Harvard University, affiliated with the David Rockefeller Center of Latin American Studies.

\section{Candidates must include, in English:}

- Curriculum vitae;

- One page explaining why the candidate wishes to study at Harvard;

- Three or four pages describing the proposed research project;

- Two letters of reference from persons who can prove the qualifications of the candidate and the importance of the proposed project.

\section{For additional information, contact:}

Visiting Scholars and Fellows Program Coordinator David Rockefeller Center for Latin American Studies Harvard University

61 Kirkland Street

Cambridge, MA 02138 USA

Tel: (617) 495-3366 Fax: (617) 496-2802

e-mail: drclas@fas.harvard.edu

Web site: http://www.fas.harvard.edu/ drclas

\section{Post-doctorate fellowship in Germany Alexander Von Humboldt Foundation}

The Alexander Von Humboldt Foundation, which exists more than 130 years and whose actual structure was established a few years after WWII (1953), is offering fellowships for post-doctorate study and for specialized research projects in all areas of knowledge. There are 500 fellowships annually, distributed without limitation of nationality, and 150 fellowships (Feodor Lynen Research Fellowships), only for German researchers and professors, to work as invited researchers of ex-fellows of all nationalities and their Universities. The Alexander Von Humboldt Foundation Fellowships are open to all professors who meet the above-mentioned requisites and who are less than 40 years of age. There is also one specialized fellowship for candidates between 40 and 45 years of age. These fellowships are for 6 to 24 months, receiving 3400 to 4200 German marks monthly.

\author{
Interested candidates should contact: \\ Alexander Von Humboldt-Stiftung \\ Jean Paul Strasse 12 \\ D-53173 BONN (Germany) \\ Telefax: 0049-228-833-199 \\ Internet: http://www.avh.de
}

Ex-fellows of the Foundation are represented in Brazil by:

"Clube Humboldt do Brasil"

Av. Brig. Faria Lima, 1572 - $7^{\circ}$ andar, sala 705

01463-900 São Paulo, SP

President Prof. Dr. Bruno Konig Junior

Department of Anatomy, ICB, USP, São Paulo, Brasil

Tel: (011)818-7258 